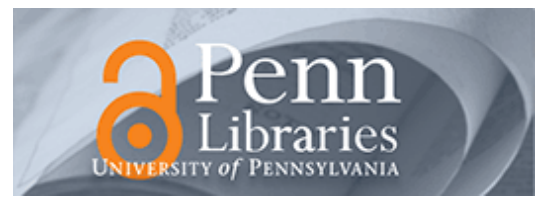

University of Pennsylvania

ScholarlyCommons

Poetics Studies Papers

Department of English

7-1-1987

\title{
Words with "All the Effects of Force: Cold-War Interpretation
}

\author{
Alan Filreis \\ University of Pennsylvania, afilreis@writing.upenn.edu
}

Follow this and additional works at: https://repository.upenn.edu/poetics_papers

Part of the English Language and Literature Commons

Filreis, Alan, "Words with "All the Effects of Force: Cold-War Interpretation" (1987). Poetics Studies Papers. 10.

https://repository.upenn.edu/poetics_papers/10

Suggested Citation:

Alan Filreis. "Words with "All the Effects of Force: Cold-War Interpretation" American Quarterly 39.2 (1987): 306-312. Copyright @ 1987 Johns Hopkins University. This article first appeared in American Quarterly, Volume 39, Issue 2, July 1987 pages 306-312. Reprinted with permission by The Johns Hopkins University Press.

This paper is posted at ScholarlyCommons. https://repository.upenn.edu/poetics_papers/10

For more information, please contact repository@pobox.upenn.edu. 


\title{
Words with "All the Effects of Force: Cold-War Interpretation
}

\author{
Abstract \\ A review of two books about cold-war prospecutions of communists becomes an essay on free speech, \\ academia, literary intention and cold-war interpretation of language. \\ Keywords \\ communism, cold war, free speech, academia \\ Disciplines \\ English Language and Literature \\ Comments \\ Suggested Citation: \\ Alan Filreis. "Words with "All the Effects of Force: Cold-War Interpretation" American Quarterly 39.2 (1987): \\ 306-312.
}

Copyright (@) 1987 Johns Hopkins University. This article first appeared in American Quarterly, Volume 39, Issue 2, July 1987 pages 306-312. Reprinted with permission by The Johns Hopkins University Press. 


\title{
WORDS WITH "ALL THE EFFECTS OF FORCE": COLD-WAR INTERPRETATION
}

\author{
ALAN FILREIS \\ University of Pennsylvania
}

The Great "Red Menace": United States Prosecution of American Communists, 1947-1952. By Peter L. Steinberg. Westport, Connecticut: Greenwood Press, 1984. 311 pages. $\$ 35.00$.

No Ivory Tower: McCarthyism and the Universities. By Ellen W. Schrecker. New York: Oxford University Press, 1986. 437 pages. \$20.95.

PETER STEINBERG'S THE GREAT "RED MENACE" TELLS THE STORY OF THE 1949 SMITH Act trial of leaders of the Communist Party of the United States (CPUSA), which culminated in the 1951 Dennis v. United States decision. In that decision the Supreme Court upheld Judge Harold Medina's ruling that the First Amendment certainly does not extend to those who conspire to advocate the violent overthrow of the American government. The exposition is brilliant: Steinberg alternates between groups of chapters written from the perspective of the government and its prosecutors on the one hand, and the beleaguered CPUSA on the other. Telling the story of the prosecution of a small and by-then uninfluential political group may not seem to require the time and space it has taken, but if we focus on a shift in the conception of American language marked by the trial and the Dennis decision, we will find plenty to go on.

The shift will seem as dramatic to "new" American literary historians as to a new, skeptical generation of legal theorists, and that is perhaps why, with the two disciplines now sharing much the same ground, Steinberg's good work is so timely. In the 1919 Schenck decision, the Supreme Court ruled that to decide if subversive language was not protected by the right to free speech the courts would have to test the direct relation between the writing and the prohibitable action. One could not shout fire in a theater if there were no fire, Justice Holmes wrote in the famous metaphor; if one did falsely shout, the falsity would be clear enough (where was the fire?), and the connection of the language shouted to the ensuing harm was present (for example, theatergoers trampling one another to get out). A court could expect the prosecution to demonstrate both clarity and presence. The high court thus used an abstract notion of proximitythat is, of language to action; of language intended to lead to action to the action itself-but tried to look away from the intention in the language and as exclusively as possible at the action, and in this way demanded the relevance of external evidence 
to the interpretation of language. Investigators and attorneys working on behalf of the American government in 1951 had no choice but to reshape the doctrine of clear - and present danger if they wanted to define American communist language as suggesting illegality; and, as Steinberg demonstrates, they wanted this very badly.

For one thing, the distance between the subversive language of the depleted postwar CPUSA and a future violent toppling of the American government was so great, the sign pointing so indirectly toward the signified, as to make the danger extremely unclear, indeed, largely absent. Lacking the external evidence that seemed required by the Schenck interpretation, the prosecutors, aides in the executive branch (guided by Truman and his attorney general), the FBI, the lower court, and eventually the high court succeeded in shifting the test from the relation between language and the world to the intention of the language itself - that is, from external evidence of a powerful state imminently endangered by subversive language to internal evidence offered in a text which "meant" future illegal action. The government was ready to devalue clear and present danger in order to place great emphasis on the most impressionistic aspect of Holmes's 1919 writing: the First Amendment, Holmes had written, "does not even protect a man from injunction against uttering words that may have all the effects of force." One easily perceives instability in the relation of utterances to effects of force, let alone the susceptibility of the idea of intentionality to abuse.

When Harold Medina instructed the jury that "words may be the instruments by which crimes are committed,' as Steinberg quotes him (Steinberg has performed the heroic task of reading the entire million-plus-word transcript of the trial), the judge was making sure the jury understood that it was their duty to interpret intention. He was "instructing" them to read the texts of subversion thus: punishable advocacy. was that which would incite illegal action "by language reasonably and ordinarily calculated to do so." At this rate-and in a moment I will turn to the Congressional hearings of writers to show this specifically_Holmes' falsely shouted "Fire!" in the theater may as well have been uttered by a player in the play for all the attention actually paid to text in context.

In order to shift attention away from the expectation that some evidence, any evidence, would be brought into the court establishing that any one of the twelve communist defendants had themselves acted illegally at a certain time, or had proposed to act illegally, or had taught others the specific duty to act illegally-no such evidence was ever introduced-the prosecution began with the witness Louis Budenz whose testimony is undoubtedly the oddest ever admitted in an American criminal trial. The strategy was to ask the judge to allow as evidence readings from "classic texts," works by or about communists, which would establish what all communists do by suggesting what one of them once intended. Anticipating that the defense, conducted by Eugene Dennis himself, would offer counterexamples of classic texts arguing for change through peaceful means, Budenz then stunned the defendants by introducing the notion of "the Aesopian language thesis." According to the Aesopian language thesis, communist language was hardly ever meant literally. CPUSA communicated in codes of 
metaphors, synecdoches, and antitheses. If Dennis produced a text which claimed "peace" as the communists' objective, it was to be read as intending "war." The trick was to catch the communist-influenced writer off his guard, saying what he really meant. Thus if a "classic text" happened to admit violence as a means, it indeed meant violence; if in the text one found "nonviolence," it too of course meant violence. If Lenin in exile wrote of conditions in "Japan," and it was well known he meant Russia, then was is not to be understood that the American Eugene Dennis "read" it to mean America?' From the moment the judge allowed the Aesopian language thesis to stand as relevant evidence, nothing the communist defendants could say about the very distant relationship between language and the world would constitute a convincing defense since the court had allowed the tautological interpretation that subversive language was misleading.

If we turn to the harassment of writers themselves, though it is not part of Steinberg's story, we can see how, following the disaster of Dennis, the Congressional investigating committees so easily put the ideological American writer in the risky position of arguing that all literary writing advocates something. Since, as the committee invariably then countered, Congress has the right to prohibit certain advocacy once it is associated with certain overt action (overthrow), the writer had no choice (if he wanted to be innocent of subversion) but to respond with an embarassingly modified version of his definition: literature was advocacy essentially severed from overt action. American writers had two options when facing investigators in search of subversive language. They could dissociate literature entirely from the political world by disconnecting texts from the acts of people who have civil rights worth defending; thus, for instance, they could seek refuge from the committee's intentional fallacy-subversive writings when interpreted invariably lead back to subversive writers-by hiding behind uncharacteristically formal readings of irony or ambiguity, a tactic Brecht made famous though he only briefly resorted to it. ${ }^{2}$ For most radical or formerly radical writers, this retreat into close readings, which undemocratically favored the skilled critic over the bumpkin congressman, was a distasteful option. It implied an interpretive elite and granted immunity, as it were, to "creative literature" while leaving other kinds of writing open to attack. The other option was to stick to the political claim of the by-then unpopular (or "old") Left that indeed "it is the nature of literature that the passions of an author congeal around issues." But after making this worn claim, one found oneself having to defend the issues and not the writing. The first option, to pose as a formalist, might keep the discussion on writing. The unfortunate consequence of the second option was to invite the committee back into the business of the historical interpretation of texts (which in reality ignored texts and focused on the writers' opinions) and so to allow the committee to reiterate its author-centered simplicities.

Mr. [Arthur] Miller [recently author of The Crucible]: I am opposed to the Smith Act and I am still opposed to anyone being penalized for advocating anything. ... It is the nature of life, and it is in the nature of literature, that the passions of an author congeal around issues. You can go from War and Peace through all the great novels 
of time and they are all advocating something....I am not here defending Communists, I am here defending the right of the author to advocate.

Mr. Sherer: Even to advocate the overthrow of the Government by force and violence?

Mr. Miller: I am now speaking, sir, of creative literature. The[r]e are risks and balances of risks.

We tend to read Miller's stand against HUAC as bold because, on the face of it, we know that he came to oppose the odious Smith Act, which permitted the government to prosecute Americans for "intending" to advocate something, and because he seemed admirably unwilling to back off from the idea that "the passions of the author" and his "issues" constituted evidence of benevolent intentionality, that is, evidence which Miller would argue indeed suggested a beneficial, not dangerous, relation to the world. In order to save the liberal-left conception of writing as invariably related to a worldmade-better, Miller was in effect willing to argue with HUAC not the nature of interpretation but the interpretation of specific texts themselves.

Fortunately that hearing never really came down to a text-by-text interpretation. But the committee did succeed in forcing Miller to concede the harmlessness of certain genres. The committee could get him to admit that, say, poetic writing could be about anything and then at the same time to concede that there had to be limits on what could be said. If literary language congeals around life's action, then it fell into the government's widening net of established subversives and subversive material. The only alternative was to make a substantial retreat and concede that some literary genres-poetry: harmless, it would commonly seem -entail less absolutely than other genres a responsibility for what the writer says about the world. Thus the "absolute" right specifically of the poet to write anything he or she wants about, say, bloody revolution, implies for the writer the evaluation of more or less dangerous genres.

Mr. Scherer: Let us go into literature. Do you believe that, today, a Communist who is a poet should have the right to advocate the overthrow of this Government by force and violence? In his literature, his poetry, or in newspapers or anything else?

(The witness confers with his counsel.)

Mr. Miller: I tell you frankly, sir, I think, if you are talking about a poem, I would say that a man should have the right to write a poem [on] just about anything.

Mr. Scherer: All right.

Mr. Jackson: Then I understand your position is that freedom in literature is absolute?

Mr. Miller: Well I recognize that these things, sir, are not: the absolutes are not absolute.

Mr. Jackson: My interpretation of your position is that it is absolute that a writer must have, in order to express his heart, absolute freedom of action. ${ }^{3}$

Rather than making Cold War hermeneutics a more exact business, then, the shift in Dennis to the subversive text itself only made the government's readings more 
arbitrary. That is, now that the court had put itself and the government's investigating agencies in the business of interpreting intent, the normal hard work of gathering external evidence could be dispensed with. So the prosecution could use the rhetoric of a text-centered interpretation (with its usual claims to objectivity, close attention, and exactitude) while actually focussing once again imprecisely on the author, the radical absolutist seeming to "express his heart." "The crime," noted Justice William O. Douglas wisely in his Dennis dissent, "then depends not on what is taught but on who the teacher is. That is to make freedom of speech turn not on what is said, but on the intent with which it is said." When Douglas wrote later about his disgust for the Dennis majority, he spoke again of the issue in terms of academic freedom, eloquently suggesting in general what Ellen Schrecker has now recovered in great specificity-that the notion of "objectivity" in American scholarship and teaching became increasingly valued in the 1950s. While objectivity was put forth even in the humanities as an absolute value, it was in a very important way a practical response to the invitation from government and universities to come to the end of ideology. "Thus those who believed in Communism and hoped it would take hold here and taught the creed became criminals," Douglas wrote about Dennis and intentionality, "while those who were more detached-that is, did not believe in Communismcould teach it with impunity. Yet from the academic viewpoint, the deeper a person was immersed in a subject and the more passionately he felt about it, the better teacher he usually was-whether the course be one on Wordsworth, Henry George or Karl Marx." 4

Douglas was alluding to the case of university professor Paul Sweezy, who taught Marxist theory at the University of New Hampshire at the time the state gave its attorney general a very broad definition of subversive language and suggested that he go find it at the local U. Here are two of the questions Sweezy declined to answer:

Did you tell the class at the University of New Hampshire on Monday, March 22, 1954, that Socialism was inevitable in this country?

Did you in [that] or in any of the other former lectures espouse the theory of dialectical materialism?

One wonders, of course, how a teacher can clearly explain dialectical materialism without even momentarily seeming to espouse it? And how was it concluded that Professor Sweezy said socialism is inevitable in this country if, in interpreting the Marxist text for his students that day in class, he said Marx himself would have argued that socialism is inevitable in countries like the United States in which certain conditions manifest themselves? The unequivocal is was made more central to the state's analysis of subversive language than the conditionally speculative would have and the relationally speculative like. Even such simplification of scholarly hypothesis assumes the teacher's language would be accurately in question during the course of the investigation; in fact, paraphrases in students' notes, subpoenaed or volunteered, would be the basis of the state's interpretation of espousal:

I have in the file here a statement from a person who attended your class, and I will 
read it in part because I don't want you to think I am just fishing. "His talk... was a glossed-over interpretation of the materialistic dialectic." Now, again, I ask you the original question. (Emphasis added)

It is to the credit of Ellen Schrecker's No Ivory Tower: McCarthyism and the Universities that the fairly well known Sweezy case ${ }^{5}$ is only mentioned along the way, for Schrecker has gone far beyond exemplary cases in locating, for the first time, a substantial population of delayed, distorted, destroyed academic careers, and, even more interestingly, in suggesting the extent to which these distortions and destructions have influenced the American conception of scholarly inquiry. Even after reading Washington state representative Albert Canwell's statement that "there isn't a student who has attended this university [the Seattle campus of the University of Washington] who has not been taught subversive activities," we are still surprised to learn from Schrecker that the response within the academic community was, with few exceptions, to follow the rule of the university president that a scholar has "a special obligation to deal in a scholarly way with controversial questions" and that if even tenured scholars strayed from such objectivity "they will lose their security." Yet what was objectivity here but a demand that one remain as close to one's most narrowly defined area of "competence" as possible? What was the "scholarly way" of dealing with difficult issues in the president's warning but a limited and timid way? Indeed, when Rutgers passed new bylaws in anticipation of an attack from the Senate Internal Security Subcommittee, it advised each anxious scholar to "remain within his own field of competence and handle controversial subjects with discretion and 'the standards of sound scholarship and competent teaching." "The scholar could freely speculate in new research and writing so long as he or she could conceive of legally proving competence in that area! We can see how this might immediately discourage speculative or interdisciplinary study. The framers of Rutgers' anticommunist bylaws left open the discovery of subversion (the academic euphemism was, and often is, "incompetence") to the same kind of interpretation as practiced by the FBI and federal prosecutors. The bylaws contained procedures for determining if a scholar's "utterances had been such as to raise grave doubt concerning his fitness" without even spelling out what most universities' anticommunist bylaws did plainly spell out, namely the provision against scholars whose utterances indicated they operated "under any outside discipline." "Utterances" could be broadly read as echoing a party line, repeating it without significant enough variation, paraphrasing it without explicit enough disclaimer (as was Sweezy's crime).

For the intellectual who resisted the changing definition of free inquiry during this time, as Schrecker clearly charts it, the world of the university was not very different from the strange world of Judge Medina's courtroom where not an act but the desire to advocate the duty to commit an act in the future was on trial, and where the most damning evidence offered came from "classic texts." Joseph Butterworth, a scholar of medieval literature in the English Department of the University of Washington, complained about the use of classic texts as "evidence" against him: "because we 
are members of the Communist Party, we are therefore responsible, by association, for all the words and deeds of the Communist movement since 1848, irrespective of time, place, nationality or context."

If utterances without context could damn a medievalist as having willingly given up objectivity, his only option, it would seem, was silence. Yet for a surprisingly long time, Schrecker teaches us, even the Fifth Amendment was taken to mean that silence signifies something. To encoded figures, synecdoches, and antitheses covered by the Aesopian language thesis now could be added the very absence of language. Silence on questions of guilt meant guilt. At Rutgers the ambiguity of the Fifth Amendment was settled when the same committee which decided that a teacher's utterances would raise grave doubts, etc., now interpreted the word "utterances" in their own statute to include silence. "The word 'utterances'," the committee reported back to the college, "would appear reasonably to include a failure to speak in circumstances in which such appropriate conduct requires that the person should speak."

A writer who attended the Dennis trial and heard the first prosecution witness introduce the Aesopian language thesis was immediately reminded of Alice in Wonderland. Although Ellen Schrecker and Peter Steinberg both succeed in describing a legal and intellectual tragedy with appropriate high seriousness, it is hardly criticism of these two fine historical studies that their readers may indeed think of the document produced at the Knave's trial. It was not in the Knave's handwriting, the White Rabbit noticed, and yet that was the oddest thing about it; so it was concluded that the Knave must have "imitated someone else's hand. ... If you didn't sign it, that only makes matters worse. You must have meant some mischief or else you'd have signed your name like an honest man."

\section{NOTES}

1. In a preface to Imperialism Lenin wrote that he would have to use "that cursed Aesopian language" to get past the Russian censors. Studying the continuous alternation between literality and code in communist-influenced writing became a popular science in the hands of Professor Stefan Possony, for example, whose friendly testimony before HUAC was given the title "Language as a Communist Weapon."

2. To the misreadings of HUAC's Robert Stripling, Brecht responded once, "No, it is not really in it. You will find, when you read it carefully..." and again, "That is not the meaning. It is not very beautiful, but I am not speaking about that." To the second evasion Stripling replied, "What does it mean?"

3. Miller's testimony before HUAC may be found in Thirty Years of Treason: Excerpts from Hearings before the House Committee on UnAmerican Activities, 1938-1968, 791-825.

4. The Court Years (New York, 1980), 94.

5. Sweezy v. New Hampshire (354 U.S. 234). 